\title{
Genetic and Physical Mapping of a Gene Conditioning Sensitivity in Wheat to a Partially Purified Host-Selective Toxin Produced by Stagonospora nodorum
}

\author{
Z. H. Liu, J. D. Faris, S. W. Meinhardt, S. Ali, J. B. Rasmussen, and T. L. Friesen
}

First, fourth, and fifth authors: Department of Plant Pathology, North Dakota State University, Fargo 58105; second and sixth authors: U.S. Department of Agriculture-Agricultural Research Service, Cereal Crops Research Unit, Northern Crop Science Laboratory, Red River Valley Agricultural Research Center, Fargo, ND 58105; and third author: Department of Biochemistry, North Dakota State University, Fargo 58105.

Accepted for publication 16 June 2004.

\begin{abstract}
Liu, Z. H., Faris, J. D., Meinhardt, S. W., Ali, S., Rasmussen, J. B., and Friesen, T. L. 2004. Genetic and physical mapping of a gene conditioning sensitivity in wheat to a partially purified host-selective toxin produced by Stagonospora nodorum. Phytopathology 94:1056-1060.

A toxin, designated SnTox1, was partially purified from culture filtrates of isolate Sn2000 of Stagonospora nodorum, the causal agent of wheat leaf and glume blotch. The toxin showed selective action on several different wheat genotypes, indicating that it is a host-selective toxin (HST). The toxic activity was reduced when incubated at $50^{\circ} \mathrm{C}$ and activity was eliminated when treated with proteinase $\mathrm{K}$, suggesting that the HST is a protein. The synthetic hexaploid wheat W-7984 and hard red

sensitive, respectively, to SnTox1. The ITMI mapping population was evaluated for toxin reaction and used to map the gene conditioning sensitivity. This gene, designated Snnl, mapped to the distal end of the short arm of chromosome 1B. The wheat cv. Chinese Spring (CS) and all CS nullisomic-tetrasomic lines were sensitive to the toxin, with the exception of N1BT1D. Insensitivity also was observed when the 1B chromosome of CS was substituted with the $1 \mathrm{~B}$ chromosome of an insensitive accession of Triticum dicoccoides. In addition, a series of 1BS chromosome deletion lines were used to physically localize the sensitivity gene. Physical mapping indicated that Snnl lies within a major gene-rich region on 1BS. This is the first report identifying a putative proteinaceous HST from S. nodorum and the chromosomal location of a host gene conferring sensitivity.
\end{abstract} spring wheat Opata 85, the parents of the International Triticeae Mapping Initiative (ITMI) mapping population, were found to be sensitive and in-

Stagonospora nodorum Berk. (syn. Septoria nodorum (Berk.), teleomorph Phaeosphaeria nodorum (syn. Leptosphaeria nodorum E. Müller) is the causal agent of Stagonospora nodorum blotch (SNB) of common wheat (Triticum aestivum L., $2 n=6 x=42$, AABBDD genomes) and durum wheat (T. turgidum L., $2 n=4 \times=$ 28 , AABB genomes). SNB is an economically important disease in many wheat-growing areas throughout the world, not only because it causes yield losses up to $50 \%(13,17,44)$, but also because it can affect grain quality $(7,24)$. Typical SNB symptoms include lens-shaped necrotic and chlorotic lesions, whereas only small restricted lesions develop on resistant genotypes.

Host-selective toxins (HSTs) are important factors in many host-pathogen interactions, and have been reported in many pathosystems (35). Most fungal-produced HSTs are nonribosomally synthesized peptides or polyketide-derived compounds, but some are small proteins (32). Proteinaceous HSTs are primary gene products, and therefore are well suited for molecular biological investigations involving the interaction between fungal pathogen and host plant. The wheat tan spot pathogen Pyrenophora triticirepentis currently is the most well-characterized fungus producing proteinaceous HSTs. The best characterized of these toxins is $\operatorname{Ptr}$ ToxA, which is a $13.2-\mathrm{kDa}$ protein that induces necrosis when infiltrated into sensitive wheat genotypes (41). The

Corresponding author: T. L. Friesen; E-mail address: friesent@ fargo.ars.usda.gov

Publication no. P-2004-0816-02R

This article is in the public domain and not copyrightable. It may be freely reprinted with customary crediting of the source. The American Phytopathological Society, 2004
Additional keywords: Leptosphaeria, Phaeosphaeria, Septoria. gene responsible for the production of the toxin has been cloned and characterized from the fungus $(2,4)$. In the host, sensitivity to the toxin is associated with susceptibility to the fungus (18) and is controlled by a single dominant gene (19). This gene was mapped on the long arm of chromosome $5 \mathrm{~B}$ using restriction fragment length polymorphisms in common wheat (8) as well as durum wheat (1).

In the case of $S$. nodorum, several chemical compounds, including cationic acid, ochracine, and septorin, have been isolated from culture filtrates. These compounds have been shown to induce symptom-like reactions on wheat leaves. However, they proved to be nonspecific and not significant determinants of disease (15). Keller et al. (16) demonstrated that crude extract of $S$. nodorum had selective action on wheat embryos originating from cultivars with different disease resistance levels. This in vitro screening method was used successfully for genetic analyses and breeding (43). However, proteinaceous HSTs have not yet been identified and isolated from $S$. nodorum.

A large, coordinated effort to develop molecular marker-based genetic linkage maps of all the wheat chromosomes began in the early 1990s with the establishment of the International Triticeae Mapping Initiative (ITMI) and utilized a population of recombinant inbred (RI) lines. Dense genetic maps of all 21 chromosomes now exist and include hundreds of marker loci $(23,29-31,33,42)$. Many major genes and quantitative trait loci (QTL) for disease resistance and agronomically important characters have been mapped using this well-characterized population $(3,9,12,21,27$, $28,38,39$ ), including the gene conferring sensitivity to Ptr ToxC, an HST produced by $P$. tritici-repentis (5).

The polyploid nature of common wheat has allowed researchers to develop a vast array of aneuploid stocks. Stocks such as 
monosomic, nullisomic-tetrasomic (NT), ditelosomic, and intervarietal disomic substitution lines are powerful tools for investigations of genetics and genomics, and they allow the physical location of genes and markers to specific chromosomes or chromosome arms $(26,37)$. Recently, more than 400 chromosome deletion lines have been developed (6). These lines allow genes and DNA markers to be located to subchromosomal regions or bins $(10,11,14,34,40)$.

The objective of this study was to physically and genetically map the gene conferring sensitivity to a partially purified HST from $S$. nodorum. Symbols for designating the toxin and the host sensitivity gene are proposed.

\section{MATERIALS AND METHODS}

Plant material. The genetic mapping population consisted of 106 RI lines (partial ITMI mapping population) derived from a cross between the synthetic hexaploid wheat W-7984 and the hard red spring wheat cv. Opata 85 (PI 591776), and was provided by M. E. Sorrells, Cornell University, Ithaca, NY. Development of this population was described in Nelson et al. (30). Wheat-cytogenetic stocks, including NT lines (37) (N2AT2D not included), chromosome 1BS deletion lines (6), Chinese Spring-T. dicoccoides (CS-DIC) disomic chromosome substitution lines (CSDIC 3A and CS-DIC 6B not included), and T. dicoccoides $(2 n=$ $4 \times=28$, AABB genomes) used to create the substitution lines were provided by the Wheat Genetics Resource Center at Kansas State University. All these lines were subjected to infiltration with partially purified toxin for genetic analysis and physical mapping. Wheat genotypes ND495, BR-34, Erik, Grandin, Kulm, and CS were used to check the activity of partially purified toxin and determine host selective properties.

Culture filtrate production and toxin partial purification. $S$. nodorum isolate $\mathrm{Sn} 2000$ was collected from a wheat field in North Dakota in 1980. Toxin-containing Sn2000 culture filtrates were generated by growing the fungus on V8-potato dextrose agar medium until pycnidia began to release spores. Each plate then was washed with $50 \mathrm{ml}$ of sterile distilled water, and $200 \mu \mathrm{l}$ of the spore suspension was added to $50 \mathrm{ml}$ of liquid Fries medium $(5 \mathrm{~g}$ of ammonium tartrate, $1.0 \mathrm{~g}$ of ammonium nitrate, $0.5 \mathrm{~g}$ of magnesium sulfate, $1.3 \mathrm{~g}$ of potassium phosphate [dibasic], $2.6 \mathrm{~g}$ of potassium phosphate [monobasic], $30.0 \mathrm{~g}$ of sucrose, $1.0 \mathrm{~g}$ of yeast extract, dissolved in 1,000 $\mathrm{ml}$ of water) and placed on an orbital shaker at $80 \mathrm{rpm}$ for $48 \mathrm{~h}$ followed by 3 weeks of stationary growth. Both growth steps took place in the dark at room temperature. Culture filtrates were filtered through two layers of cheese cloth followed by vacuum filtration through a Whatman No. 1 filter and a $0.45-\mu \mathrm{m}$ Whatman cellulose nitrate filter. Culture filtrate $(100 \mathrm{ml})$ was concentrated 16-fold using an Amicon YM10 membrane, diluted 9-fold with $20 \mathrm{mM}$ glycyl-glycine, $\mathrm{pH}$ 8.0 , and concentrated to $3 \mathrm{ml}$. The dilution with glycyl-glycine was repeated once and the concentrated 3-ml sample passed through a DEAE Sepharose Fast Flow column, 1.6 by $12 \mathrm{~cm}$. The flow-through was collected, concentrated to $3 \mathrm{ml}$, and separated on a Superdex HR75 column (Pharmacia), 1.6 by $60 \mathrm{~cm}$, equilibrated with $20 \mathrm{mM}$ sodium acetate and $150 \mathrm{mM} \mathrm{NaCl}, \mathrm{pH} 4.8$. Active fractions were combined and used for assays.

Infiltration of partially purified toxin and toxin partial characterization. Plants were grown in plastic cones containing SB100 professional grow mix (Sungrow Horticulture, Dellevue,
WA) in the greenhouse at an average temperature of $21^{\circ} \mathrm{C}$ with a 12 -h photoperiod. Two replicates of at least three plants of each parent, the RI lines, and cytogenetic stocks were infiltrated with the partially purified toxin. When the secondary leaf was fully expanded, it was assayed by infiltrating $\approx 25 \mu \mathrm{l}$ of partially purified toxin using a 1-ml syringe with the needle removed. The boundaries of the infiltration sites were marked with a nontoxic felt pen before water-soaking disappeared. After infiltration, all plants were moved to a growth chamber at $21^{\circ} \mathrm{C}$ with a 12 -h photoperiod. Leaves were evaluated 3 days after infiltration and scored as insensitive or sensitive. Sensitive reactions were characterized by necrosis, whereas insensitivity showed no reaction within the infiltrated area.

To identify the putative proteinaceous nature of this toxin, the partially purified toxin samples along with samples treated with proteinase $\mathrm{K}$ at $1 \mathrm{mg} \mathrm{ml}^{-1}$ were incubated at both room temperature and $50^{\circ} \mathrm{C}$ for $4 \mathrm{~h}$. Proteinase $\mathrm{K}$ at $1 \mathrm{mg} \mathrm{ml}^{-1}$ alone was used as a control (Table 1). The untreated and treated samples along with the control were infiltrated into the leaves of the toxinsensitive cv. Grandin. The toxin activity was assayed by scoring plant leaves as sensitive or insensitive as mentioned previously.

The size of the toxin in culture filtrates was identified using size-based ultrafiltration. Filtrates and concentrates were tested using cutoff filters of 5, 10, and $30 \mathrm{kDa}$ (Millipore, Billerica, MA). Filtrates and concentrates were infiltrated as described previously using toxin-sensitive cv. Grandin.

Linkage analysis. The mapping data for the ITMI population was obtained from the Graingenes database. The phenotypic data of the toxin reaction was treated as a marker locus and tested for linkage with the data set of 541 markers spanning the entire genome. The computer program MAPMAKER (version 2.0 for Macintosh) (20) was used to calculate linkage of the toxin-sensitivity gene with molecular markers using a minimum log likelihood ratio (LOD) of 3.0.

\section{RESULTS}

In vitro reaction of partially purified toxin. The reaction of several common wheat genotypes to the partially purified toxin was either sensitive or insensitive. Among them, ND495, Grandin, Kulm, and CS showed sensitivity (necrosis) within the infiltrated area, but lines BR34 and Erik both were insensitive to the toxin. The two parents used to develop the ITMI population also showed a differential reaction to this toxin, with W-7984 being sensitive and Opata 85 being insensitive (Fig. 1, top). The selective action of this partially purified toxin preparation on different genotypes suggested that it contains a host-selective toxin.

Activity assay of partially purified toxin after temperature, proteinase $K$ treatment, and size-based filtration. Partially purified toxin incubated at room temperature and at $50^{\circ} \mathrm{C}$ showed necrosis 3 days postinfiltration (Table 1; Fig. 1, bottom). However, neither partially purified toxin samples treated with proteinase $\mathrm{K}\left(1 \mathrm{mg} \mathrm{ml}^{-1}\right)$ nor proteinase $\mathrm{K}\left(1 \mathrm{mg} \mathrm{ml}^{-1}\right)$ alone showed necrosis when infiltrated into sensitive wheat leaves (Table 1; Fig. 1, bottom).

Concentrates of all size-based filtration experiments induced necrosis when infiltrated into sensitive cv. Grandin. Filtrates of the 5- and $10-\mathrm{kDa}$ filter did not induce necrosis, whereas filtrates of the $30-\mathrm{kDa}$ filter did induce necrosis, indicating that the toxin is between 10 and $30 \mathrm{kDa}$.

TABLE 1. Effect of partially purified SnTox1 on sensitive wheat leaves after temperature and proteinase K treatment

\begin{tabular}{lcc}
\hline & & Reaction temperature $(4 \mathrm{~h})$ \\
\cline { 2 - 3 } Treatment & Room temperature & $50^{\circ} \mathrm{C}$ \\
\hline Partially purified toxin alone & Sensitive & Sensitive \\
Partially purified toxin treated with proteinase $\mathrm{K}\left(1 \mathrm{mg} \mathrm{ml}^{-1}\right)$ & Insensitive & Insensitive \\
Proteinase $\mathrm{K}\left(1 \mathrm{mg} \mathrm{m}^{-1}\right)$ alone & Insensitive & Insensitive \\
\hline
\end{tabular}



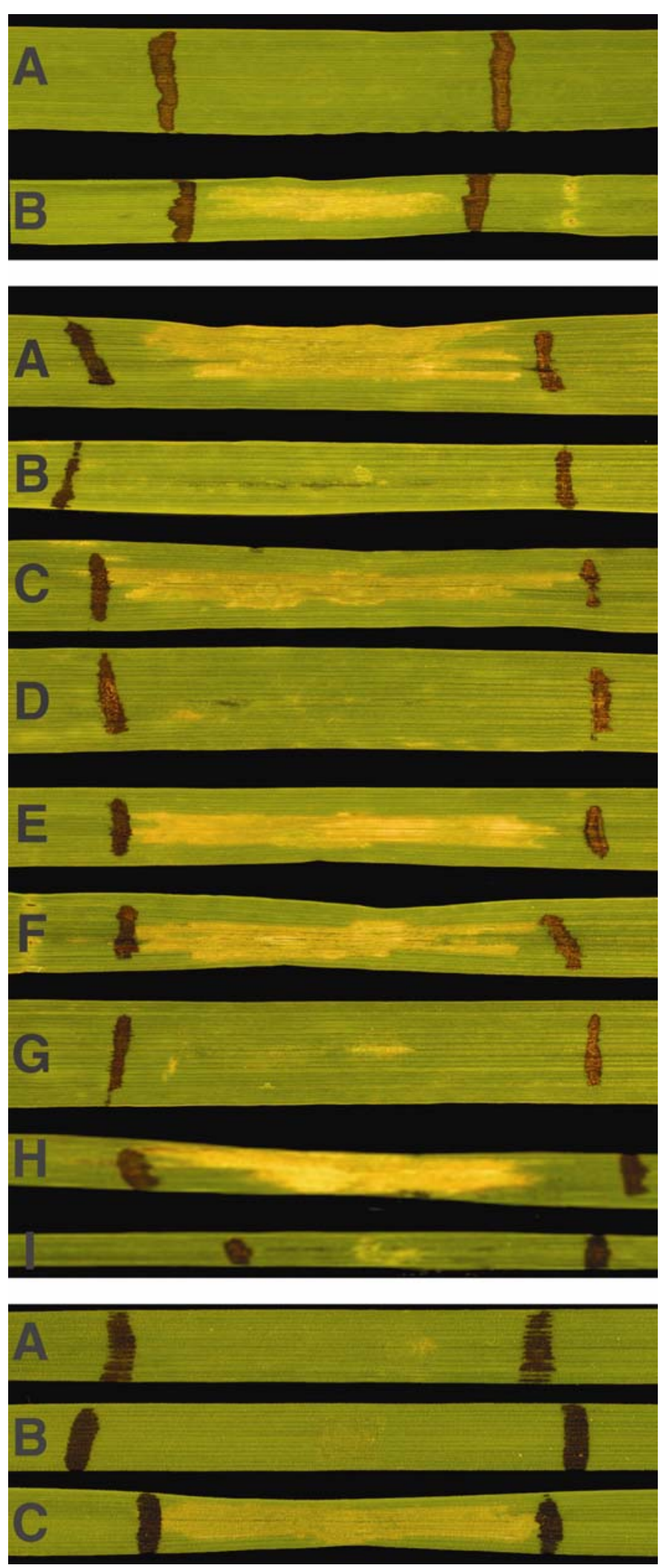

Fig. 1. Reaction of leaves 3 days after infiltration with the partially purified toxin produced by Stagonospora nodorum isolate Sn2000 and the partially purified toxin treated with proteinase K. Top panel: Leaves from the parents of International Triticeae Mapping Initiative population: A, Opata 85, B, W7984; middle panel: A, Chinese Spring, B, Triticum dicoccoides, C, N1AT1D, D, N1BT1D, E, N1DT1B, F, CS-DIC1A, G, CS-DIC1B, H, CS1BS-4, I, CS1BS-18; bottom panel: leaves of Grandin treated with A, proteinase K only at $1 \mathrm{mg} / \mathrm{ml}, \mathbf{B}$, partially purified toxin treated with proteinase $\mathrm{K}$ at $1 \mathrm{mg} / \mathrm{ml}$, and $\mathbf{C}$, partially purified toxin only.
Genetic mapping of toxin insensitivity. The RI population segregated in a ratio of 48:58 sensitive/insensitive and were consistent with the expected $1: 1$ ratio after $\chi^{2}$ analysis $\left(\chi^{2}=0.33\right)$. This suggests that a single nuclear gene is responsible for conferring reaction to the partially purified toxin from the $S$. nodorum isolate Sn2000. Linkage analysis revealed that the toxin-sensitivity locus is located at the distal end of the short arm of chromosome $1 \mathrm{~B}$ at a distance of 4.7 centimorgans (cM) from the marker XksuD14 (Fig. 2).

Physical mapping of toxin sensitivity. CS was found to be sensitive to the Sn2000 HST, and an accession of T. dicoccoides used to create disomic chromosome substitution lines in CS was found to be insensitive (Fig. 1, middle). Among the set of CS-DIC substitution lines and CS NT lines, only CS-DIC1B and N1BT1D showed insensitive reactions (Fig. 1, middle), Therefore, this result correlated with the genetic linkage mapping result in that the toxin sensitivity gene resides on chromosome $1 \mathrm{~B}$.

To further refine the physical location of the Sn2000 HST sensitivity gene, we screened six CS chromosome 1B short arm deletion lines. Infiltration analysis revealed that all 1BS deletion lines were insensitive to the toxin, with the exception of $1 \mathrm{BS}-4$ (Fig. 1, middle), which is the most terminal chromosome deletion. Therefore, the physical location of the toxin sensitivity gene lies between the breakpoints of 1BS-4 and 1BS-18 (Fig. 2).

\section{DISCUSSION}

Sn2000 is an aggressive isolate of $S$. nodorum that was collected in North Dakota. Using filtration, ion-exchange, and gel filtration chromatography, we partially purified a toxin from culture filtrates of this isolate. Some reports of chemical toxic compounds purified from $S$. nodorum exist, but most of these toxic compounds do not appear to be HSTs and are likely secondary metabolites or general cell wall-degrading enzymes (15). Culture filtrates that did show selective action in previous studies $(16,43)$ were tested only on embryos and never were partially purified or characterized. In our study, the partially purified toxin from Sn2000 was shown to pass through a $30-\mathrm{kD}$ a cutoff filter but not through a 5- or $10-\mathrm{kDa}$ filter, indicating a size of between 10 and $30 \mathrm{kDa}$. Toxin action also was found to be labile to the treatment of proteinase K. Size and sensitivity to proteinase K both suggest that the toxin is proteinaceous in nature. Even though multiple proteins are present with this partially purified toxin, it is hypothesized that only one protein is host selectively active as a toxin due to the 1:1 segregation of host sensitivity. The isolation and characterization of this putative protein is in progress. There is no precedent for naming toxins from $S$. nodorum; therefore, we propose SnTox1 to designate this toxin, which is the first proteinaceous HST identified from $S$. nodorum.

In general, host-selective toxins are recognized as primary determinants (pathogenicity factors) of disease, and they delimit the host range of the fungal pathogen. Victorin is an HST produced by Cochliobolus victoriae Nelson that infects only oat (Avena sativa L.) with the genetically dominant $V b$ gene (25). Another known HST is HC toxin, produced by $C$. carbonum race 1 , and is necessary to cause disease only in toxin-sensitive maize lines (36). ND495, Kulm, Grandin, and CS are sensitive to SnTox1 and susceptible to isolate Sn2000. In contrast, Erik and BR34 are insensitive to SnTox1 and highly resistant to Sn2000. In related work, we evaluated the ITMI population for reaction to fungal inoculation of Sn2000. A major QTL was identified at the toxin-sensitivity locus, and it accounted for a large portion of the phenotypic variation (22). It appears that SnTox1 plays an important role in disease development and appears to be a major virulence factor.

In the wheat- $P$. tritici-repentis interaction, Ptr ToxA also is considered an important factor in the development of tan spot. Insensitivity to the toxin often is correlated with resistance to the 


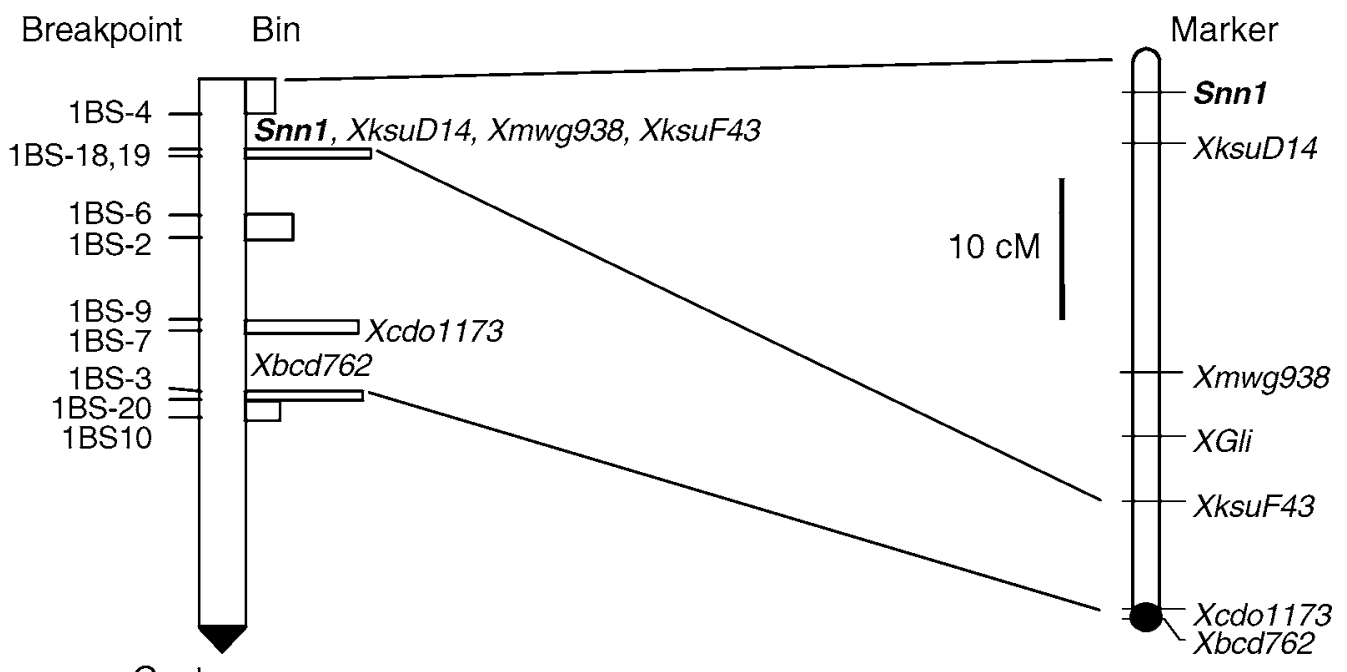

Fig. 2. Comparison between the physical and genetic maps of wheat chromosome 1BS. The toxin sensitivity locus is designated Snn1. On the physical map, deletion bins are indicated by the boxes to the right of the chromosome. On the genetic map, markers are listed at the right. The centimorgan (cM) distance between $\mathrm{Snn} 1$ and XksuD14 is 4.7 .

fungus. In addition, sensitivity to the toxin is controlled by a dominant gene. It was suggested that Ptr ToxA requires interaction with the product of the host sensitivity gene to manifest necrosis (1). In this study, we found that CS N1BT1D and the CS-DIC1B substitution line are insensitive to SnTox1. This insensitivity can be explained by the fact that the sensitivity gene was absent because of the absence of CS 1B. The toxin-sensitivity locus on chromosome 1B may be a sensitivity gene that produces a protein that directly or indirectly interacts with SnTox1 and gives rise to a sensitive reaction. The genetics of the SnTox 1 and Ptr ToxA wheat interactions are very similar despite the fact they are produced by two different pathogens. It may be that such mechanisms were evolutionarily conserved by different pathogens.

Comparison of the physical and genetic map (Fig. 2) indicates that the toxin-sensitivity gene and DNA markers $X k s u D 14$, $X m w g 938, X G l i$, and XksuF43 all map on 1BS. The deletion bin harboring these markers accounts for $\approx 7 \%$ of the physical size of the $1 \mathrm{~B}$ short arm (34). The corresponding segment of the genetic linkage map accounts for $\approx 27 \mathrm{cM}$ and is one of two gene-rich regions along the short arm of chromosome 1B. This region and the homologous regions of $1 \mathrm{AS}$ and 1DS also harbor many disease resistance genes ( $\mathrm{Lr} 21, \mathrm{Sr} 33, \mathrm{Pm3}$, and Qndsu.Tsc), agronomically important genes ( $R f 3, Q p h s . c n l$, and seed storage proteins), and more than 50 DNA markers $(14,34)$. Here, we propose the symbol Snnl to designate the gene on 1BS that confers the sensitivity to the toxin produced by isolate $\mathrm{Sn} 2000$ of S. nodorum. The marker $X k s u D 14$ has been converted to a polymerase chain reaction-based STS marker and would be suitable for markerassisted selection.

SNB is one of the most important fungal diseases in wheat; however, to date, little research has been done regarding the hostpathogen interaction. We are the first to identify a putative proteinaceous HST of $S$. nodorum and provide the genetic and physical map locations of the toxin-sensitivity gene. These discoveries will greatly facilitate the understanding of the mechanism of pathogenicity and resistance in the $S$. nodorum-wheat pathogen system.

\section{ACKNOWLEDGMENTS}

This research was supported by USDA-ARS CRIS 5442-22000-03000D and 5442-21000-026-00D. We thank P. Meyer for technical assistance.

\section{LITERATURE CITED}

1. Anderson, J. A., Effertz, R. J., Faris, J. D., Francl, L. J., Meinhardt, S. W., and Gill, B. S. 1999. Genetic analysis of sensitivity to a Pyrenophora tritici-repentis necrosis-inducing toxin in durum and common wheat. Phytopathology 89:293-297.

2. Ballance, G. M., Lamari, L., Kowatsch, R., and Bernier, C. C. 1996. Cloning, expression and occurrence of the gene encoding the Ptr necrosis toxin from Pyrenophora tritici-repentis. Mol. Plant Pathol. Online Publication no. 1996/1209ballance.

3. Börner, A., Schumann, E., Fürste, A., Cöster, H., Leithold, B., Röder, M. S., and Weber, W. E. 2002. Mapping of quantitative trait loci determining agronomic important characters in hexaploid wheat (Triticum aestivum L.). Theor. Appl. Genet. 105:921-936.

4. Ciuffetti, L. M., Tuori R. P., and Gaventa, J. M. 1997. A single gene encodes a selective toxin causal to the development of tan spot of wheat. Plant Cell 9:135-144.

5. Effertz, R. J., Meinhardt, S. W., Anderson, J. A., Jordahl, J. G., and Francl, L. J. 2002. Identification of a chlorosis-inducing toxin from Pyrenophora tritici-repentis and the chromosomal location of an insensitivity locus in wheat. Phytopathology 92:527-533.

6. Endo, T. R., and Gill, B.S. 1996. The deletion stocks of common wheat. J. Hered. 87:295-307.

7. Eyal, Z. 1981. Integrated control of Septoria disease of wheat. Plant Dis. 65:763-768

8. Faris, J. D., Anderson, J. A., Francl, L. J., and Jordahl, J. G. 1996. Chromosomal location of a gene conditioning insensitivity in wheat to a necrosis-inducing culture filtrate from Pyrenophora tritici-repentis. Phytopathology 86:459-463.

9. Faris, J. D., Anderson, J. A., Francl, L. J., and Jordahl, J. G. 1997. RFLP mapping of resistance to chlorosis induction by Pyrenophora triticirepentis in wheat. Theor. Appl. Genet. 94:98-103.

10. Faris, J. D., and Gill, B. S. 2002. Genomic targeting and high-resolution mapping of the domestication gene $Q$ in wheat. Genome 45:706-718.

11. Faris, J. D., Haen, K. M., and Gill, B. S. 2000. Saturation mapping of a gene-rich recombination hot spot region in wheat. Genetics 154:823-835.

12. Faris, J. D., Li, W. L., Liu, D. J., Chen, P. D., and Gill, B. S. 1999. Candidate gene analysis of quantitative disease resistance in wheat. Theor. Appl. Genet. 98:219-225.

13. Fried, P. M., and Meister, E. 1987. Inheritance of leaf and head resistance of winter wheat to Septoria nodorum in a diallel cross. Phytopathology 77:1371-1375.

14. Gill, K. S., Gill, B. S., Endo, T. R., and Taylor, T. 1996. Identification and high-density mapping of gene-rich regions in chromosome group 1 of wheat. Genetics 144:1883-1891.

15. Jørgensen, H. J. L., and Smedegaard-Petersen, V. 1999. Host-pathogen interactions in the Septoria-disease complex. Pages 131-160 in: Septoria on Cereals-A Study of Pathosystems. J. A. Lucas, P. Bowyer, and H. M. Anderson, eds. IACR-Long Ashton Research Station, Bristol, UK. 
16. Keller, B., Winzeler, H., Winzeler, M., and Fried, P. M. 1994. Differential sensitivity of wheat embryos against extracts containing toxins of Septoria nodorum: First steps towards in vitro selection. J. Phytopathol. 141:233-240

17. King, J. E., Cook, R. J., and Melville, S. C. 1983. A review of Septoria diseases of wheat and barley. Ann. Appl. Biol. 103:345-373.

18. Lamari, L., and Bernier, C. C. 1989. Toxin of Pyrenophora triticirepentis: Host-specificity, significance in disease, and inheritance of host reaction. Phytopathology 79:740-744.

19. Lamari, L., and Bernier, C. C. 1991. Genetics of tan necrosis and extensive chlorosis in tan spot of wheat caused by Pyrenophora tritici-repentis. Phytopathology 81:1092-1095.

20. Lander, E. S., Green, P., Abrahamson, J., Barlow, A., Daly, M. J., Lincoln, S. E., and Newberg, L. 1987. MAPMAKER: An interactive computer package for constructing primary genetic linkage maps of experimental and natural populations. Genomics 1:174-181.

21. Li, W. L., Faris, J. D., Chittoor, J. M., Leach, J. E., Hulbert, S. H., Liu, D. J., Chen, P. D., and Gill, B. S. 1999. Genomic mapping of defense response genes in wheat. Theor. Appl. Genet. 98:226-233.

22. Liu, Z. H., Friesen, T. L., Meinhardt, S. W., Ali, S., Rasmussen, J. B., and Faris, J. D. 2004. Quantitative trait loci analysis and mapping of seedling resistance to Stagonospora nodorum leaf blotch in wheat. Phytopathology 94:1061-1067.

23. Marino, C. L., Nelson J. C., Lu, Y. H., Sorrells, M. E., Leroy, P., Tuleen, N. A., Lopes, C. R., and Hart, G. E. 1996. Molecular genetic maps of the group 6 chromosomes of hexaploid wheat (Triticum aestivum L. em. Thell.). Genome 39:359-366.

24. McKendry, A. L., Henke, G. E., and Finney, P. L. 1995. Effects of Septoria leaf blotch on soft red winter wheat milling and baking quality. Cereal Chem. 72:142-146.

25. Meehan, F., and Murphy, H. C. 1947. Differential toxicity of metabolic by products of Helminthosporium victoriae. Science 106:270.

26. Morris R., Schmidt, J. W., Mattern, P. J., and Johnson, V. A. 1966. Chromosomal location of genes for flour quality in the wheat variety 'Cheyenne' using substitution lines. Crop Sci. 6:119-122.

27. Nelson, J. C., Autrique, J. E., Fuentes-Dávila, G., and Sorrells, M. E. 1998. Chromosomal location of genes for resistance to Karnal bunt in wheat. Crop Sci. 38:231-236.

28. Nelson, J. C., Singh, R. P., Autrique, J. E., and Sorrells, M. E. 1997. Mapping genes conferring and suppressing leaf rust resistance in wheat. Crop Sci. 37:1928-1935.

29. Nelson, J. C., Sorrells, M. E., Van Deynze, A. E., Lu, Y. H., Atkinson, M., Bernard, M., Leroy, P., Faris, J. D., and Anderson, J. A. 1995. Molecular mapping of wheat: Major genes and rearrangements in homoeologous groups 4, 5, and 7. Genetics 141:721-731.

30. Nelson, J. C., Van Deynze, A. E., Autrique, E., Sorrells, M. E., Lu, Y. H.,
Merlino, M., Atkinson, M., and Leroy, P. 1995. Molecular mapping of wheat. Homoeologous group 2. Genome 38:516-524.

31. Nelson, J. C., Van Deynze, A. E., Autrique, E., Sorrells, M. E., Lu, Y. H., Negre, S., Bernard, M., and Leroy, P. 1995. Molecular mapping of wheat. Homoeologous group 3. Genome 38:525-533.

32. Panaccione, D. G., Johnson, R. D., Rasmussen, J. B., and Friesen, T. L. 2002. Fungal phytotoxins. Pages 311-339 in: The Mycota XI. Agricultural Applications. Kempken, ed. Springer-Verlag, Berlin, Heidelberg.

33. Röder, M. S., Korzun V., Wendehake, K., Plaschke, J., Tixier, M.-H., Leroy, P., and Ganal, M. W. 1998. A microsatellite map of wheat. Genetics 149:2007-2023.

34. Sandhu, D., Champoux, J. A., Bondareva, S. N., and Gill, K. S. 2001. Identification and physical localization of useful genes and markers to a major gene-rich region on wheat group $1 \mathrm{~S}$ chromosomes. Genetics 157:1735-1747.

35. Scheffer, R. P. 1983. Toxins as chemical determinants of plant disease. Pages 1-40 in: Toxins and Plant Pathogenesis. J. M. Daly and B. J. Deverall, eds. Academic Press, New York.

36. Scheffer, R. P., and Ullstrup, A. J. 1965. A host-specific toxic metabolite from Helminthosporium carbonum. Phytopathology 55:1037-1038.

37. Sears, E. R. 1966. Nullisomic-tetrasomic combinations in hexaploid wheat. Pages 29-45 in: Chromosome Manipulations and Plant Genetics. R. Riley and K. R. Lewis, eds. Oliver and Boyd, London.

38. Singh, R. P., Nelson, J. C., and Sorrells, M. E. 2000. Mapping Yr28 and other genes for resistance to stripe rust in wheat. Crop Sci. 40:1148-1155.

39. Sourdille, P., Perretant, M. R., Charmet, G., Leroy, P., Gautier, M. F., Joudrier, P., Nelson, J. C., Sorrells, M. E., and Bernard, M. 1996. Linkage between RFLP markers and genes affecting kernel hardiness in wheat. Theor. Appl. Genet. 93:580-586.

40. Sutka, J., Galiba, G., Vagujfalvi, A., Gill, B. S., and Snape, J. W. 1999. Physical mapping of the Vrn-Aland Frl genes on chromosome 5A of wheat using deletion lines Theor. Appl. Genet. 99:199-202.

41. Tuori, R. P., Wolpert, T. J., and Ciuffetti, L. M. 1995. Purification and immunological characterization of toxic components from cultures of Pyrenophora tritici-repentis. Mol. Plant-Microbe Interact. 8:41-48.

42. Van Deynze, A. E., Dubcovsky, J., Gill, K. S., Nelson, J. C., Sorrells, M. E., Dvořák, J., Gill, B. S., Lagudah, E. S., McCouch, S. R., and Appels, R. 1995. Molecular-genetic maps for group 1 chromosomes of Triticeae species and their relation to chromosomes in rice and oat. Genome 38: 45-59.

43. Wicki, W., Messmer, M., Winzeler, M., Stamp, P., and Schmid, J. E. 1999. In vitro screening for resistance against Septoria nodorum blotch in wheat. Theor. Appl. Genet. 99:1273-1280.

44. Wicki, W., Winzeler, M., Schmid, J. E., Stamp, P., and Messmer, M. 1999. Inheritance of resistance to leaf and glume blotch caused by Septoria nodorum Berk. in winter wheat. Theor. Appl. Genet. 99:1265-1272. 